\title{
Growing Pains: Challenges for a Rising China
}

\section{Citation}

Perry, Elizabeth J. 2014. “Growing Pains: Challenges for a Rising China." Daedalus 143 (2) (April): 5-13.

\section{Published Version}

doi:10.1162/daed_a_00268

\section{Permanent link}

http://nrs.harvard.edu/urn-3:HUL.InstRepos:12038954

\section{Terms of Use}

This article was downloaded from Harvard University's DASH repository, and is made available under the terms and conditions applicable to Open Access Policy Articles, as set forth at http:// nrs.harvard.edu/urn-3:HUL.InstRepos:dash.current.terms-of-use\#OAP

\section{Share Your Story}

The Harvard community has made this article openly available.

Please share how this access benefits you. Submit a story.

Accessibility 


\section{Growing Pains: Challenges for a Rising China}

\section{Elizabeth J. Perry}

The accumulative achievements of China's ongoing socioeconomic reforms are by most measures little short of astounding. From one of the globe's poorest countries at the time of Mao Zedong's death in 1976, the People's Republic of China (PRC) has become a booming economy-second biggest in the world-thanks to a swift rise that has rescued hundreds of millions of its people from poverty and afforded the government enviable resources for further development. Yet while one may marvel at the speed and success of the so-called China miracle, neither the Chinese people nor their leaders seem at ease with the current situation. Rampant grassroots protest bespeaks intense popular indignation at everything from land grabs to environmental pollution, while top officials themselves rail against the corroding effects of cadre corruption and income inequality.

To evaluate the challenges facing China after thirty-five years of reform is a difficult task, and not only because of the apparent disconnect between objective gains and subjective gripes. For one thing, the head-spinning pace of change threatens to render any academic assessment quickly obsolete. For another, the PRC's post-Mao record of achievement is in fact decidedly uneven across geographic regions, social strata, and policy sectors. While major cities boast gleaming new infrastructure and attendant urban amenities that equal or surpass those of the advanced industrial world, much of the rural interior remains mired in grinding poverty. The affluence of new urban middle and upper classes, flush with the proceeds from lucrative real estate deals, is offset by the indigence of the millions of migrants who labor in their midst. And although the Chinese state can take credit, at least through the 1990s, for spearheading a series of bold economic measures that replenished central coffers and enriched many citizens, post-Mao achievements in the area of social welfare-not to mention political and legal reform-have to date been less impressive.

The project of "reform and opening" (gaige kaifang), launched by reformist politician Deng Xiaoping in December 1978, only two years after Mao Zedong's death, brought both unprecedented prosperity and unparalleled problems. The most immediate initial challenge facing Deng and his colleagues was that of preserving Communist Party rule while dismantling the command economy and regimented social order that constituted defining yet debilitating features of classic Communist systems. This was a feat that had eluded most other Communist states. In subsequently characterizing his reform effort as "socialism with Chinese characteristics," Deng Xiaoping drew attention to the distinctiveness of the Chinese trajectory.

Swift as China's ascent has been, it has not been seamless. The contradiction between an increasingly open economy and society and a still intact Leninist party-state came to a dramatic head only a decade into the post-Mao reform effort with the Tiananmen uprising of 1989, when millions of citizens joined hands to criticize inflation and corruption and to call for political reform. That was also the year, of course, when Communist regimes collapsed across Eastern Europe, soon to culminate in the breakup of the Soviet Union itself. In China, the state's brutal suppression of the Tiananmen uprising, followed by its sustained attention to "stability maintenance" (weiwen), has deterred the resurgence of massive political protests. Yet among ordinary Chinese citizens as well as government officials, not to mention Western social 
scientists, there is widespread skepticism of the long-term compatibility between a flourishing market economy and a conventional Communist polity.

$* * *$

From the very beginning of the reform era, the apparent incongruity in the basic makeup of the Chinese political economy has prompted persistent predictions of imminent regime change from outside observers. Significantly, however, this same sense of precariousness has helped motivate successive generations of Chinese Communist Party (CCP) leaders to invent and implement an array of policies intended to preempt-or at least postpone-the need for a drastic political overhaul. For the first three decades of reform, as the state dismantled the rudimentary welfare provisions of the Mao era, it looked as though the only thing that could be considered socialist about "socialism with Chinese characteristics" was the continued rule of a ruthless Communist Party. Basking in the glow of stunning and sustained economic growth, party leaders were able to disregard many of the negative externalities that emerged in the wake of rapid marketization.

Much has changed in recent years. Leaders evidence growing awareness of the danger of hitching the legitimacy and longevity of their Communist party-state to an economic engine whose velocity is slowing. The second term of the Hu Jintao-Wen Jiabao administration (20072012) saw a flurry of government regulations and initiatives intended to redress many of the social ills and grievances that had accrued during the previous thirty years of extremely rapid yet highly unequal growth. New labor laws, medical insurance schemes, pensions, poverty alleviation programs, and higher-education expansion formed part of an ambitious bid to secure popular support and thereby sustain party rule. The newly installed Xi Jinping-Li Keqiang leadership seems committed to deepening a comprehensive project of social reform, while at the same time declaring war on the rampant cadre corruption that has become a lightning rod for popular discontent. The $\mathrm{Xi}-\mathrm{Li}$ administration openly acknowledges worrisome economic indicators to underscore the need for further fiscal reform. Moreover, with the fate of the political system believed to hang in the balance, party-state leaders express urgency for making progress on a range of policy challenges that extend well beyond GDP growth rates. The Mass Line Campaign, launched in June 2013, enjoins party cadres to eschew extravagance in order to avoid the loss of popular support believed responsible for the collapse of the Soviet Union.

Progressive social policies and stricter party discipline, buttressed by solid economic reform, are not the only means by which the $\mathrm{CCP}$ endeavors to stay in power. What the state euphemistically refers to as "social management" (shehui guanli), or the resolution of social tensions through a potent mixture of coercion and accommodation, remains a staple instrument of control that helps account for the absence of large-scale political demonstrations in the twenty-five years since Tiananmen. Press and Internet censorship are an important element of this strategy. Another factor in the CCP's capacity to defuse political challenge is the leaders' proven aptitude for "cultural governance," or the invention and application of resonant symbolic resources designed to enhance the party's image and endear it to the people. ${ }^{1}$ Rather than simply suppress unwelcome media reports or blog postings, for example, the authorities take an active role in planting their own interpretation of events so as to "guide public sentiment" (yindao yuqing) in directions favorable to the party's agenda. These various techniques have deep roots

\footnotetext{
${ }^{1}$ Elizabeth J. Perry, Anyuan: Mining China's Revolutionary Tradition (Berkeley: University of California Press, 2012).
} 
in the history of the CCP as both a revolutionary and a ruling party, but they have been substantially modified and modernized to suit contemporary conditions. ${ }^{2}$

In light of the demise of Communist party-states across most of the globe, it may be tempting to discount the CCP's contemporary policy experiments as a desperate ploy by a soonto-be doomed regime. But the post-Mao state has already survived-and indeed thrived-for far too long not to be taken seriously as a subject for comparative public policy investigation. Moreover, the historical origins of the PRC suggest that its future may not be well predicted by the fates of the former Soviet Union or East European Communist regimes. ${ }^{3}$ The PRC-like all other still extant Communist regimes (that is, Cuba, Vietnam, Laos, and North Korea)-ascended to power via an extended rural revolution that endowed the regime and its ruling Communist Party with strong nationalist credentials. This stands in contrast to the Communist Party of the Soviet Union, which gained control through a relatively short and narrowly based urban revolution. The difference with Eastern Europe, where Communist regimes were generally imposed by Soviet military might at the end of World War II, is even sharper. Unlike most of the formerly Communist world, the PRC and its few fellow surviving Communist states attained power in the course of prolonged and pervasive peasant mobilization. That rich revolutionary history bequeathed valuable practical experience in social organization and control, while bestowing important political advantages that have so far withstood the test of time. This is by no means to suggest that such regimes are destined to last forever, but whatever the PRC's eventual life span turns out to be, its remarkable rise and resilience to date suggest that we are better advised to treat its current challenges and complaints as the growing pains of a body politic still in the process of maturation, not as the death pangs of a Communist dinosaur destined to imminent extinction.

Thus, rather than frame our inquiry in terms of the prospects for regime change, as so much social science work on contemporary China is apt to do, the contributors to this issue of Doedalus were invited to explore ways in which the Chinese state is addressing actual policy concerns, from popular protest to public health. Although these policy challenges may be especially pronounced and politically sensitive in China, in light of the country's exceptional size and rapid economic growth under a basically unreformed Communist political system, they are also problems common to all countries. Contributors were encouraged to assess the Chinese state's record in a comparative context, highlighting what is unique or unusual (for better or worse) in the PRC's efforts to resolve these universal dilemmas.

This collective exercise yields a complex portrait of a government and society that are tackling at once, with varying degrees of success, a broad range of issues that bedevil developed and developing countries alike. Some of the thorniest challenges, ironically enough, stem either directly or indirectly from the remarkable results of earlier PRC reform efforts, including the one-child-family program and the rural industrialization boom. From dramatic demographic transition to devastating environmental degradation, the ensuing problems are often intractable and the solutions seldom entirely obvious or easy. In contrast to some other countries, however,

\footnotetext{
${ }^{2}$ Elizabeth J. Perry, "Cultural Governance in Contemporary China: Re-Orienting Party Propaganda," HarvardYenching Institute Working Paper Series (2013).

${ }^{3}$ Sebastian Heilmann and Elizabeth J. Perry, eds., Mao's Invisible Hand: The Political Origins of Adaptive Governance in China (Cambridge, Mass.: Harvard University Press, 2011); and Martin K. Dimitrov, ed., Why Communism Did Not Collapse: Understanding Authoritarian Regime Resilience in Asia and Europe (New York: Cambridge University Press, 2013).
} 
the Chinese case is noteworthy for a growing recognition of the seriousness of these questions on the part of both government officials and ordinary citizens.

Somewhat paradoxically, perhaps, China's lack of democratic processes and institutions contributes to the urgency with which such policy challenges are regarded. For example, in a context where massive protests ignited by medical malpractice or environmental pollution are viewed as capable of detonating the entire system, the apparent danger of inaction is intensified and the political dividend for alleviating such problems is amplified. While it is certainly true that the absence of democratic channels for expressing and redressing popular grievances is itself responsible for the severity of a number of these troubles, that same democratic deficit puts immense pressure on the government leadership to arrive at effective solutions. To be sure, the draconian methods employed by the Chinese state to address some of its challenges would be deemed both unfeasible and unpalatable in a more liberal political setting. Even so, the fact that many of the problems with which China is currently grappling are global in compass and consequence renders its public policy record of more than parochial interest and importance.

$$
* * *
$$

Without democratic institutions capable of conferring procedural legitimacy, the ability of the PRC to meet its pressing policy challenges will depend to some degree upon continued economic expansion capable of generating adequate employment opportunities and financing critical redistributive and other government-led programs. While the sizzling growth rates of the initial decades of reform are unsustainable over the long run, a steady pace of development is vital to realizing the state's ambitious social policy agenda. As Barry Naughton points out in his essay in this volume, China is already exceptional among large economies in its unusually high level of state investment. Linking this overinvestment (compounded by financial fragility, local government debt, demographic changes, and other systemic shortcomings) to an inevitable economic slowdown, Naughton argues nonetheless that "serious market-oriented economic reforms are possible in the immediate future." So long as central leaders act preemptively in promoting a financial restructuring to blunt the power of vested interests (including their own), the Chinese economy can move to a lower but more sustainable growth rate in the context of a richer, more prosperous society. Naughton stresses that "[i]t absolutely has the capacity to do so, but policy-makers must summon the will and determination." The previous $\mathrm{Hu}-\mathrm{Wen}$ administration proved unable to meet this politically difficult challenge; whether the $\mathrm{Xi}-\mathrm{Li}$ leadership will rise to the task remains to be seen.

Even under the most optimistic of economic scenarios, however, it is clear that the state will need to overcome a number of vexing social problems. Among the most serious, as Deborah Davis observes in her essay, is the demographic issue. Decades of low fertility encouraged by the single-child-family policy have contributed to a rapidly aging population. The deleterious consequences are particularly pronounced in the countryside, where massive out-migration has left elderly villagers with no adult children to provide support. While the problem of an aging population is nothing new for many countries in the developed world, Davis points out that "China will become old before the country becomes rich." The dilemma is intensified by the fact that wealth in China is so unevenly distributed. Martin Whyte notes in his contribution that "China has experienced an unusually sharp increase in income inequality since the early 1980s and currently ranks fairly high compared to other societies in terms of the gaps between its rich and poor citizens." This inequality, Whyte explains, conforms closely to spatial lines that were 
drawn during the Mao era. ${ }^{4}$ To overcome such deeply entrenched divisions between city and countryside will demand bold and wide-ranging reform.

Among the most pressing reforms required to blunt the impact of rural poverty are improvements in health care provision. Yet, as William Hsiao emphasizes in his essay, the quality and accessibility of medical care in contemporary China also follows the spatial divide: "The disparity in access to quality health care between rural and urban areas has in essence created a two-tiered system. Although the top level is similar to health care available in firstworld nations, the lower tier of the Chinese health care system is more typical of that found in the third world." The solution, Hsiao argues, will require more than simply increased state investment. In fact, he cautions that "more investment in health may not improve health outcomes." Nothing short of a fundamental reorientation in medical ethics, combined with a major restructuring of public hospital governance, will do the trick. Despite this grim assessment of the problems bedeviling the Chinese health system, Hsiao's comparison with another large developing country, India, puts the Chinese record in a more favorable light. After a decade of government attention on the part of both countries to providing health care to the rural poor, China has managed to extend medical insurance to 95 percent of its citizens whereas India has succeeded in covering a scant 25 percent of its population.

As Mark Frazier reminds us, how we evaluate China's relative progress on social policy (including old-age pensions, public education, and affordable housing, in addition to health care) depends on the cross-national comparison set. The most common sets of countries against which China is typically assessed, the East Asian developmental states and the post-socialist transitional economies, may not be the most appropriate or illuminating for this purpose. According to Frazier, a more useful grouping is what he calls "large uneven developers" (such as India, Brazil, and South Africa) with legacies of severe rural-urban inequality combined with periods of rapid economic growth. Put in this framework, the Chinese policy path emerges as quite distinctive, although the comparative efficacy of its "more categorical and spatial" approach to overcoming the urban-rural divide remains to be seen, especially should the Chinese state be faced with a sudden and sharp economic downturn.

Posing a particular challenge to the PRC's commitment to poverty alleviation is the dismal plight of hundreds of millions of internal migrants. The continuing structural divide between city and countryside-reinforced by a "household registration" (hukou) system that remains officially intact, despite the emergence of a "floating population" (liudong renkou) whose actual places of residence (in cities) do not match their official (rural) status-makes this a slippery issue for the state to address. Compounding the state's difficulties is the growing activism of young migrant workers whose increased mobilization and awareness of their legal rights, Mary Gallagher contends, "stands in sharp contrast to the state of labor movements in other transitional and developing countries." To deal with the upsurge in large-scale strikes and demonstrations, the state has intervened more directly in the dispute resolution process in a move that Gallagher characterizes as "problematic for the rule of law and the fledgling legal system."

Gallagher's conclusion is consistent with that of Benjamin Liebman, who further suggests that the Chinese party-state's preference for rapid conflict resolution over adherence to legal procedures may actually be serving to engender even greater social instability. Because the Chinese Communist Party does not derive its own legitimacy from the law, its commitment to the legal process is inherently weak. A rise in popular protest over the past decade has been met

\footnotetext{
${ }^{4}$ For more on the Mao-era origins of China's urban-rural divide, see Jeremy Brown, City versus Countryside in Mao's China: Negotiating the Divide (New York: Cambridge University Press, 2012).
} 
by a retreat from legal reform in favor of what Liebman calls a "return to populist legality," or the reliance on dispute mediation led by local party officials. Ironically, this effort to dampen rampant protest by party mediation seems to have had precisely the opposite of its intended effect, encouraging yet other complainants "to pursue their grievance outside the legal system," thus promoting even more unrest.

Coping with a high level of protest is certainly nothing new for the Chinese political system. Popular protest has been a staple feature of state-society relations in China for centuries. Imperial China, Republican China, and Mao's China were all beset by widespread societal contention that severely tested state control. ${ }^{5}$ Despite this continuity, the modes and meanings of social protest and state response have fluctuated markedly, reflecting profound changes in both concerns and capacities. Among the most striking recent developments has been the turn to the Internet and other forms of new social media on the part of aggrieved citizen activists and attentive state officials alike. Guobin Yang explains in his essay that the areas and sites of government regulation and control have expanded in tandem with changes in citizen activism: "Today, content and service regulation is all-encompassing, including Internet cafés, bulletin board systems, text-messaging, online news, video and audio sharing websites, online games, and blogs and microblogs." Managing and channeling online contention is but one of a number of adaptive state techniques for coping with new modes of popular protest. Ching Kwan Lee points out in her essay that ever since the run-up to the Beijing Olympics in 2008, the Chinese state has also resorted increasingly to a practice that officials call "buying stability"-bargaining with protesters by offering them cash payments-as a means of deterring or defusing street demonstrations and other disruptive activities. Although the approach has helped depoliticize state-society interactions, Lee argues that this "turn to the market as a mechanism of governance" holds a number of corrosive implications, of which the most serious may be a decline in state authority.

$* * *$

Throughout Chinese history, "heterodox" religions helped inspire and instigate anti-state contestation. That historical heritage, compounded by Marxism-Leninism's hostility toward religion in general, contributes to the party-state's suspicion toward all manner of spiritual beliefs and practices-from Falun Gong to Islam. The remarkable religious upsurge now sweeping China thus triggers special political concerns. The state has, unsurprisingly, been slow to bestow official recognition on the myriad of new religious groups that have emerged. As Robert Weller explains, the response of Chinese officials has been to "govern with one eye closed," or "simply leave religion alone as long as they feel that no lines have been crossed," rather than to change the official regulatory system to conform to the new reality. Hypocritical though this stance may be, it allows the state to manage the situation without revamping its basic corporatist model.

While state authorities are reluctant to abandon or overhaul the fundamental system of social control, they have not been shy about experimentation in a range of key policy domains. William Kirby's essay on higher education explores one of the most dynamic policy arenas in contemporary China. The phenomenal explosion in university enrollments and commensurate expansion in campus size and facilities reflect a major state investment in the development of higher education. Yet as Kirby notes, the state's strategy "has been elitist as well as massive." Aiming to promote a privileged stable of "world class" universities capable of competing with

\footnotetext{
${ }^{5}$ Elizabeth J. Perry, Challenging the Mandate of Heaven: Social Protest and State Power in China (Armonk, N.Y.:
} M.E. Sharpe, 2002). 
top-ranked institutions around the globe, the Chinese government has been pouring enormous sums of money into a handful of its leading universities, a strategy that exacerbates preexisting divisions between privileged and disprivileged students and faculty. By Kirby's account, the jury is still out on a haunting question facing China's educational ambitions: "can 'world-class' universities . . . exist in a politically illiberal system?"

China's policies in the field of higher education are obviously influenced by the pressures and promises of "global rankings," which raise high hopes of being able to clamber up to the top tier on the basis of certain objective and universally acknowledged benchmarks. But Jeffrey Wasserstrom, citing the insight of British historian C. A. Bayly with respect to an earlier age of globalization, points out that the relentless drive toward international uniformity does not necessarily imply homogenization: "[t]oday, as well, it is useful to see globalization as leading to standardization without the eclipsing of difference." Drawing on examples as far afield as world exhibitions and world religions, Wasserstrom shows how China's adoption of common crossnational forms has in turn filled them with distinctive national content.

The two concluding essays point to serious issues of governance that may well stand in the way of China's aspirations, global and domestic alike. The essay by Joseph Fewsmith and Gao Xiang highlights a "crisis in local governance" that shields grassroots officials from accountability and subverts Beijing's efforts to build a service-oriented government. As central leaders move away from a singular focus on economic growth to a broader array of concerns encompassing corruption control, stability maintenance, social welfare, and environmental protection, the interests and incentives of central and local governments are no longer closely aligned. To date, Beijing's reluctance to tighten the reins on the localities has redounded in its favor by deflecting public grievances from central to local authorities, but the continuation of this decentralized administrative system means that "the people who have borne much of the cost of this rapid development have been those who should have been its beneficiaries: the local residents."

The decentralized governance system also presents major problems for environmental protection, an issue that is of growing concern not only to China's own residents but to the global community at large. Pollutants from China's coal-fired power plants fall as acid rain on Seoul and Tokyo, and even much of the particulate pollution hanging over Los Angeles these days reportedly originates in China. ${ }^{6}$ Observing that China's environmental protection record fares badly by almost any comparative measure, Elizabeth Economy places the blame squarely on the system of governance: "At the heart of the Chinese government's inability to protect the environment is the country's own particular mix of political institutions, processes, and incentive structures." While this administrative configuration may have served China surprisingly well during the preceding decades of head-spinning economic growth, it appears less well suited to the more diverse policy agenda that the center is increasingly anxious to pursue. Echoing the conclusion of other essays in this issue of Doedalus, Economy detects "an uneasy, often politically fraught situation defined by official adherence to traditional, often ineffectual modes of government policy-making at the national level and crisis-management at the local level." Yet she also looks more hopefully to a rising urban middle class, armed with Internet access, that "is changing the relative power dynamic between the state and society."

$$
* * *
$$

\footnotetext{
${ }^{6}$ Joseph Kahn and Jim Yardley, "As China Roars, Pollution Reaches Deadly Extremes," The New York Times, August 26, 2007.
} 
In short, China's ongoing process of "reform and opening" remains fluid and highly unpredictable. While few would deny the stunning strides of the past thirty years, the very successes of earlier programs and policies have generated new and difficult problems that may well demand a more thoroughgoing reconfiguration of political institutions and operations than the top leadership has yet been willing to undertake. But this does not necessarily mean that democratization is on the immediate horizon. Nor does it relieve us of responsibility for taking a serious look at the ways in which China is coping with current dilemmas. However long or short the future of the Chinese Communist system may be, the complex challenges of attaining and balancing goals of economic development, official accountability, environmental protection, poverty reduction, and social equity will surely remain high on both Chinese and global agendas.

Taken as a whole, the PRC's approach to policy challenges is in many ways unique, thanks to the country's unusual size and regional diversity, as well as to its distinctive revolutionary history and current political-economic configuration. Yet as the essays in this volume demonstrate, placing particular policy approaches in comparative perspective is illuminating, not least because different policy domains evoke different parallels. China's rapid economic growth invites comparison to the other developmental states of East Asia, while its difficulties in delivering social welfare may be better understood in the context of other large and uneven late developers like India and Brazil. The Communist party-state's response to Internet activism and social unrest might seem at first blush comparable only to other authoritarian systems, yet several of the essays draw telling comparisons (and contrasts) with the United States as well.

Thinking comparatively about global dilemmas is of more than academic interest. We live today in a fragile yet interdependent post-Cold War world troubled by serious transnational challenges that range from pandemics and climate change to financial meltdowns and terrorism. Institutions of governance as different as the Chinese Communist Politburo and the U.S. Congress find themselves severely tested both ideologically and operationally in trying to address such issues. We would be foolhardy to disregard or discount China's efforts to resolve global problems simply because we predict that its political system is some day destined to disappear.

Elizabeth J. Perry, a Fellow of the American Academy since 2002, is the Henry Rosovsky Professor of Government at Harvard University and Director of the Harvard-Yenching Institute. Her many books include Shanghai on Strike: The Politics of Chinese Labor (1993), Patrolling the Revolution: Worker Militias, Citizenship, and the Modern Chinese State (2005), and Anyuan: Mining China's Revolutionary Tradition (2012). 